\title{
CURRENT STATE OF AGRO-TOURISM AND DEVELOPMENT PRECONDITIONS IN ARMENIA
}

\author{
NARINE VARDANYAN \\ National Academy of Sciences of the Republic of Armenia, \\ International Scientific-Educational Center, \\ Head of Education Qual ity Assurance Department, Lecturer, \\ PhD in Philological Sciences, Associate Professor \\ narine.vardanyan@isec.am \\ GAYANE GHARAKHANYAN \\ National Academy of Sciences of the Republic of Armenia, \\ International Scientific-Educational Center, \\ Master's degreestudent \\ itgayane@gmail.com
}

\author{
ANZHELA GHALAMDARYAN \\ National Academy of Sciences of the Republic of Armenia, \\ International Scientific-Educational Center, \\ Sociologist at the Qual ity Assurance Department, \\ YSU, PhD student \\ anzhela.ghal amdaryan@isec.am
}

ANNA MRYAN

National Academy of Sciences of the Republic of Armenia, International Scientific-Educational Center,

Master's degree student

anna.myan@edu.isec.am

https://doi.org/10.52853/25792903-2021.2-nvgg

A bstract

Agrotourismis developing very fast worldwide, and Armenia is not left out of those rates of development There are serious preconditions for the development of agro-tourism in Armenia. This study aims to reveal the current state of agro-tourism outlining the development preconditions in Armenia, particularly the role of PR in the development of this field. To collect the necessary information, we used the methods of expert and in depth interviews, document analysis and viewing.

The studied data refer to gastro-houses, house-studios, adventure tourism and other interesting directions of agro-tourism, which were spread in the Republic of Armenia until the first half of 2020 and were in different regions, in particular: Gegharkunik, Vayots Dzor, Shirak, Lori, Kotayk, Tavush, Aragatsotn, Ararat. 
The results of the research allow us to conclude that:

- Agro-tourism has prospects for devel opment in Armenia;

- Agro-tourism can contribute to the development of different villages and communities in the Republic of Armenia;

- Planning PR campaigns is a necessary precondition for development;

- The lack of a common tourism platform in the Republic of Armenia hinders the development.

- The expansion of packages offering rural tourism by Armenian tour operators will contribute to devel opment.

- It is possible to create a network of guest houses, which will include only the ones that are engaged in agro-tourism

Keywords and phrases: agro-tourism, agro-tourismin Armenia, tourism business, public relations.

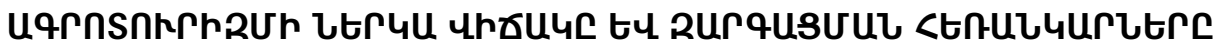 cUsuUsulnhu}

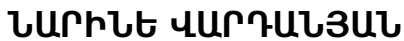

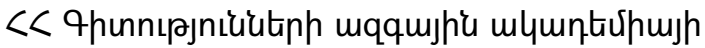

9punulynpulymiu úpremqqujhu ltiunnnu,

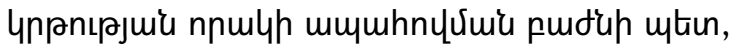

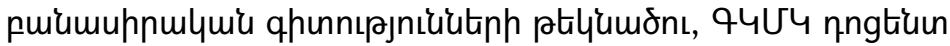

narine.vardanyan@isec.am

\section{quзuఒt qurutuulsul}

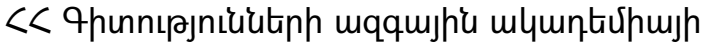

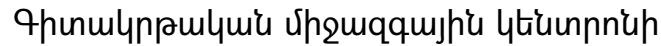

umqhuinnuiun

itgayane@gmail.com

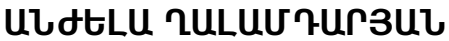

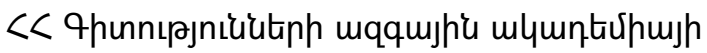

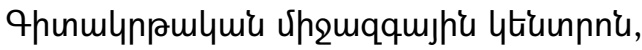

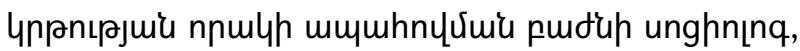
七T< uumphuiun anzhela.ghalamdaryan@isec.am 


\section{uしuU Ursul}

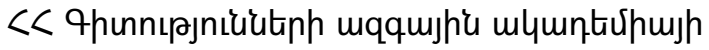

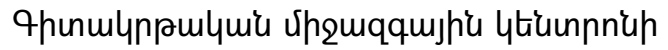

vimquinnuiun

anna.mryan@edu.isec.am

\section{Cunuunnunuqhp}

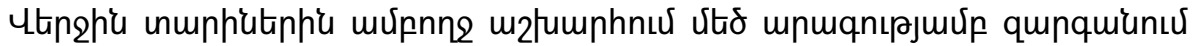

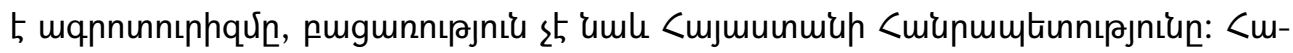

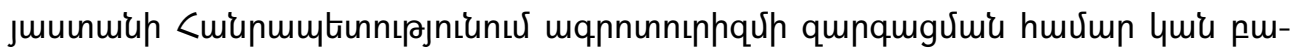

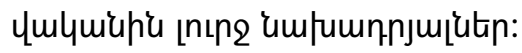

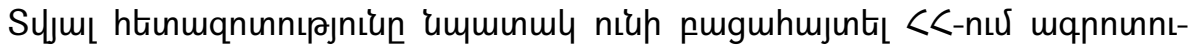

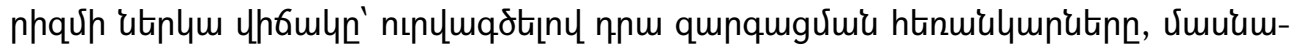

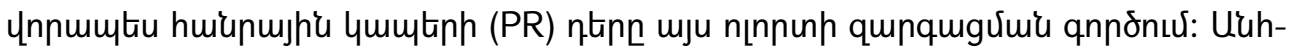

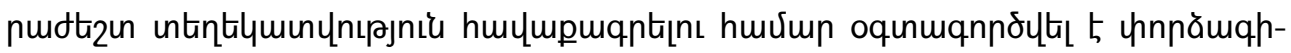

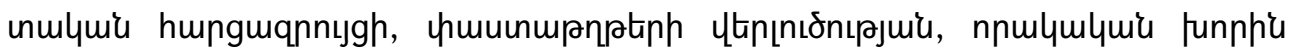

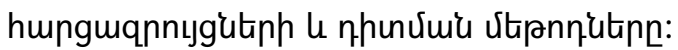

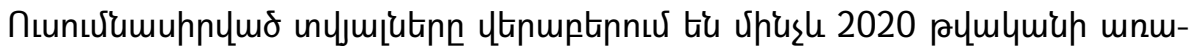

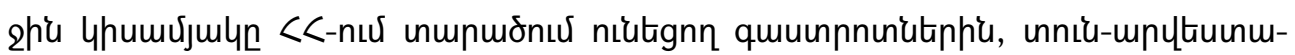

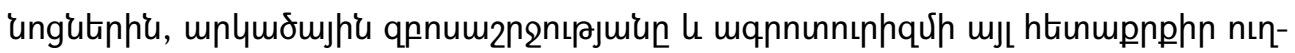

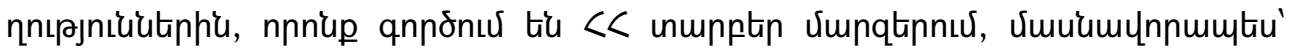

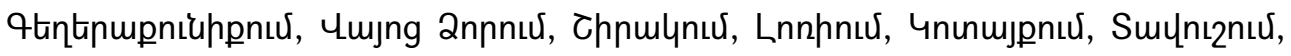
Unmquirnunup, Unmemuinh umpqtinnuर:

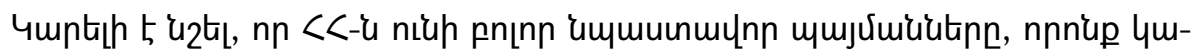

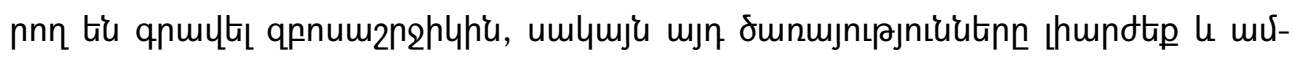

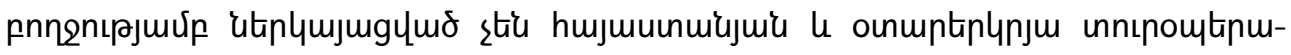

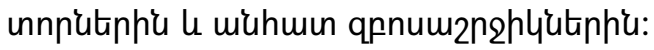

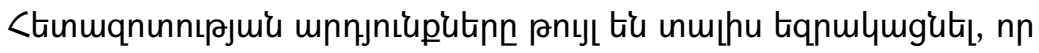

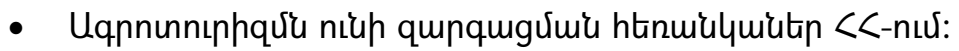

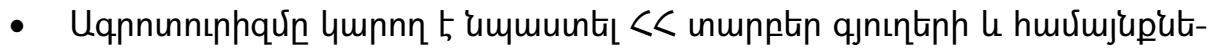
nh qunqugưumun:

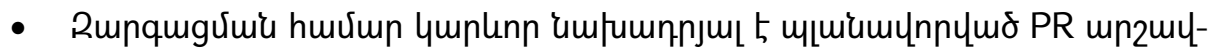
utrph quqưulytpumnúu:

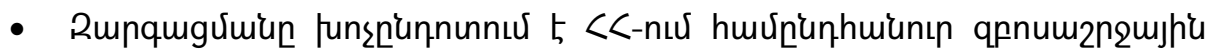

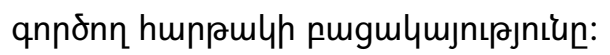




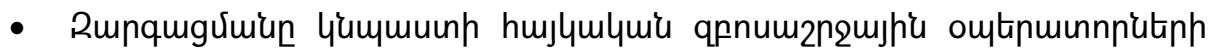

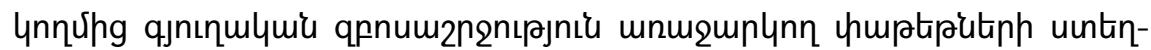

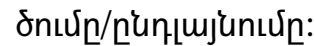

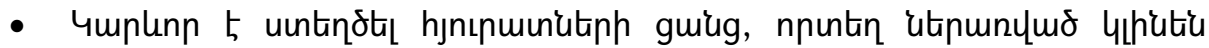

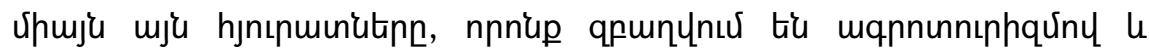

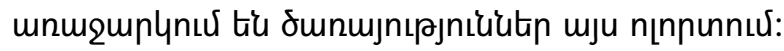

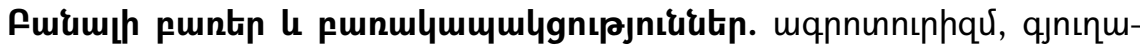

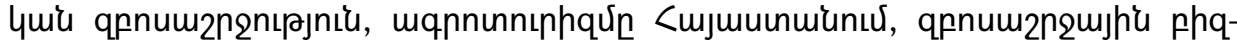
utu, huiunmshi qumitn:

\title{
НЫНЕШНЕЕ СОСТОЯНИЕ И ПЕРСПЕКТИВЫ РАЗВИТИЯ АГРОТУРИЗМА В АРМЕНИИ
}

\author{
НАРИНЕ ВАРДАНЯН \\ Национальная академия наук Республики Армения \\ Международный научно-образовательный центр \\ заведующая отделом обеспечения качества образования, \\ кандидат филологических наук, доцент \\ narine vardanyan@isec.am \\ ГАЯНЕ КАРАХАНЯН \\ Национальная академия наук Республики Армения \\ Международный научно-образовательный центр \\ магистр \\ itgayane@gmail.com
}

\begin{abstract}
АНЖЕЛА ГАЛАМДАРЯН
Национальная академия наук Республики Армения Международный научно-образовательный центр социолог отдела обеспечения качества образования

Аспирант ЕГУ

anzhela.ghal amdaryan@isec.am
\end{abstract}

\begin{abstract}
АННА МРЯН
Национальная академия наук Республики Армения Международный научно-образовательный центр магистр anna.mryan@edu.isec.am
\end{abstract}

\begin{abstract}
Аннотация
В последние годы во всем мире с большой скоростью развывается агротуризм, и Армения не исключение. В Республике Армения есть достаточно серьезные
\end{abstract}


предпосылки для развития агротуризма. Данное исследование имеет целью раскрытие нынешного состояния агротуризма в РА, отмечая перспективы его развития, в частности, роль PR-a в развитии данной отрасли. Для сбора необходимой информации использовались методы экспертного интервью, анализа документов, углубленных качественных интервью и наблюдения.

Исследуемые данные относятся к гастротам, хаус-студиям, приключенческому туризму и другим интересным направлениям агротуризма, которые были распространены в Республике Армения до первой половины 2020 года и находились в разных регионах, в частности: Гегаркуник, Вайоц Дзор, Ширак, Лори, Котайк, Тавуш, Арагацотн, Арарат.

Следует отметить, что в Армении есть все условия, которые могут привлечь туриста, но эти услуги не в полной мере предоставляются армянским и зарубежным туроператорам и индивидуальным туристам.

Результаты исследования позволяют сделать вывод, что:

- В Армении есть перспективы развития агротуризма.

- Агротуризм может способствовать развитию различных деревень и общин в Армении.

- Организация PR-кампаний - необходимое условие для развития.

- Развитию препятствует отсутствие в Армении общей туристической платформы.

- Разработка армянскими туроператорами пакетов, предлагающих сельский туризм, будет способствовать развитию агротуризма .

- Возможно создание сети гостевых домов, в которую войдут только те гостевые дома, которые занимаются агротуризмом.

Ключевые слова и словосочетания: агротуризм, агротуризм в Армении, туристический бизнес, общественные связи.

\section{Introduction}

Agrotourism is developing very fast worldwide, and Armenia is not left out of those rates of development. In recent years, infrastructure development in the tourism sector, the construction and reopening of hotels in the regions, the improvement of highways and the construction of new ones, the operation of ropeways have created preconditions in presenting Armenia as a tourist country to the world.

The field of article study examination is one of the modern developing types of tourism, the preconditions of developing agro-tourism in the Republic of Armenia. This study aims to reveal the current state of agro-tourism, outlining the 
development preconditions in Armenia. To collect the necessary information, we used the methods of in-depth interviews and document analysis.

Our research shows that advertising and literate public communication in the field of agro-tourism will promote:

- Presentation of the Republic of Armenia as an agro-tourism country, consequently, increase of the number of tourists interested in this direction,

- Tourismbusiness development;

- Proportional development of regions;

- Mitigation of villages' and peasants' social problems;

- Ensuring the employment of a large part of the society;

- Presentation and publicity of agricultural products.

\section{The development of agro-tourism}

Tourism is one of the world economy's fastest-growing sectors. In many countries, it is the primary source of income, and in some countries, $70-80 \%$ of the national income comes exclusively from tourism [2, p. 73-83]. In the last five years, one out of every five jobs has been opened in the field of tourism ([5]). $10.4 \%$ of the world's GDP, or \$ 8.8 trillion, comes from tourism [4]. Along with the development of conventional types of tourism, modem ones are emerging, one of which is agrotourism or rural tourism Agro-tourism is the organization of recreation in a rural area. It allows tourists to learn about running a farm get acquainted with the production of agricultural products, taste natural, fresh, healthy food, and take advantage of the opportunity to organize entertainment in uncommon conditions [3, p. 190-194].

Thus, agro-tourism results from the interaction between agriculture and tourism; this interaction is manifested throughout recreation planning.

The development of agro-tourism is directly related to the processes of urbanization, as the population increase in urban areas is usually accompanied by a decrease in the population of rural ones, which in its turn causes limitations for the urban population to communicate with nature, rural life and environment. These preconditions al so stimulate the demand for agro-tourism [5].

Agro-tourism has several features that contribute to the expeditious development of this type of tourism business. The followings are crucial.

1. Available almost for all segments as it is relatively low-priced [3, p. 191].

2. Agro-tourism as a rule, is family tourism, which contributes significantly to the development of children's moral and psychological upbringing and diligence [3, p. 192]. 
3. The organization of agro-tourism does not require many investments. Here, the leading investor is the villager [3, p. 192].

4. The development of agro-tourism contributes to the activation of rural life and the development of social infrastructure and culture in the village [7].

By a proper organization of agro-tourism, it is achievable.

- Provide income to the locals, which enables them to preserve and develop the natural environment;

- Create and expand international connections;

- Provide funding for the protection of natural ecosystems [8].

Agro-tourism is entirely developed in European countries. $56 \%$ of the population of the $27 \mathrm{EU}$ member states live in rural areas, which cover $91 \%$ of the entire EU territory. It suggests that political developments in rural areas are more than necessary [1, p. 9-10]. In developed European countries, agro-tourism is the second after the coastal one and provides 20-30\% total income of the tourismindustry [9].

In the European Union, several main models of agro-tourism are currently distinguished [9].

\begin{tabular}{|c|l|}
\hline B ritish & $\begin{array}{l}\text { Based on the co-existence of the tourists and farmers. Services include } \\
\text { horse and foot recreation, which is characteristic of ecotourism Today, } \\
\text { basic services have been supplemented by fishing. A novelty is the } \\
\text { creation of farms providing services related to the historical tourism of a } \\
\text { certain era. }\end{array}$ \\
\hline German \\
$\begin{array}{l}\text { The main idea is the work done by tourists in agricultural areas, the } \\
\text { joint-life and communication between them and the hosts. Thus, there } \\
\text { are two types of agro-tourism in Germany: agro-tourism, which is } \\
\text { combined with residence and work, as well as ethno-tourism, which } \\
\text { involves the participation of various folk festivals and holidays. }\end{array}$ \\
\hline French & $\begin{array}{l}\text { The main elements of this model are cooking and winemaking. Here the } \\
\text { tourist is provided with a separate house with a full menu of local } \\
\text { cuisine, including cheese, brandy, wine drinks, etc. }\end{array}$ \\
\hline Italian & $\begin{array}{l}\text { This model is similar to the French but differs in its colour; it includes } \\
\text { not only culinary but also entertainment programs, sports events, visits } \\
\text { to historical sites. Italy offers tourists grape harvest, cultivation, olive } \\
\text { harvest etc.. }\end{array}$ \\
\hline
\end{tabular}

In terms of tourist visits, Armenia has been quite prosperous in recent years. Besides the traditional historical and cultural tourism many foreign tourists prefer to visit Armenia for agro-tourism [11]. The beautiful nature, historical and cultural heritage of Armenia, the peculiarities of the Armenian cuisine, the warmth of 
hospitality play an essential role in developing agro-tourism It can be said that agrotourism is a form of profitable al ternative economic activity for the regions [12].

In recent years, the development of infrastructure in the tourism sector, the construction and reopening of hotels in the regions, the improvement of highways and the construction of new ones, the operation of ropeways have created preconditions in terms of presenting Armenia as a tourist country to the world.

Agro-tourism is developing both at the state level and due to the private business. There are many villages in Armenia, which through certain investments can become famous centres of agro-tourism Still, without targeted advertising, agrotourism can not provide a large flow of tourists to Armenia [13].

The existence of various programs is vital for this issue.

Since 2016, gastro-yards have been opened in Armenia within the UN-funded program "Integrated Rural Tourism Development" framework. The project is implemented jointly with the RA Ministry of Territorial Administration and Infrastructure. Its goal is to create 50-60 new destinations for rural tourism [14]. Each recoverable gastronomy must belong to the villager, not the state, and provide additional income to the village or family. In addition, the hospitality of Armenians dramatically contributes to the development [15]. All this will contribute to the formation of local infrastructure, will stimulate the growth of tourism in remote villages of Armenia [16].

Below are some of the gastronomes.

\begin{tabular}{|c|c|l|}
\hline The name & $\begin{array}{c}\text { The } \\
\text { location }\end{array}$ & \multicolumn{1}{|c|}{ The main services } \\
\hline $\begin{array}{c}\text { K amancha } \\
\text { M useum }\end{array}$ & Ashtarak & $\begin{array}{l}\text { Cultural and gastronomic services: opportunity to seea } \\
\text { collection of kamanchas in the museum inside the yard, } \\
\text { kamancha making-teaching master classes, Armenian } \\
\text { music and delicious food [17]. }\end{array}$ \\
\hline $\begin{array}{c}\text { Noravank } \\
\text { guest house }\end{array}$ & Chiva & $\begin{array}{l}\text { Overnight, delicious traditional Armenian food and } \\
\text { unforgettable entertainment for foreigners. }\end{array}$ \\
\hline $\begin{array}{c}\text { M atevosyan } \\
\text { Arman } \\
\text { Hakhverdy } \\
\text { an }\end{array}$ & Areni & $\begin{array}{l}\text { Yssortment of delicious food and drinks, master classes in } \\
\text { pottery, tasting of homemade honey. }\end{array}$ \\
\hline $\begin{array}{c}\text { Old Hearth } \\
\text { Hin Ojakh }\end{array}$ & Ashtarak & $\begin{array}{l}\text { Assortment of traditional delicious dishes and wine [18]. } \\
\text { pokhindi, dried fruit, sujuk, alan, baking lavash, as well as } \\
\text { craft master classes. }\end{array}$ \\
\hline
\end{tabular}


ART -

takard
Opportunity to walk in the scul pture garden of the house studio, traditional Armenian dishes, acquaintance with the works of Armenian contemporary artists, opportunity to try your hand at Armenian calligraphy [19].

There are exciting directions of agro-tourism in Armenia, the famous ones of which are presented below.

\begin{tabular}{|c|c|c|}
\hline $\begin{array}{l}\text { The } \\
\text { name }\end{array}$ & The location & The main services \\
\hline $\begin{array}{l}\text { Kalav } \\
\text { an }\end{array}$ & $\begin{array}{l}\text { Gegharkunik } \\
\text { region, } \\
\text { Kalavan } \\
\text { village }\end{array}$ & $\begin{array}{l}\text { Adventure tourism with the possi bility of living } \\
\text { in the stone age, organization of forest cuisine, } \\
\text { heal thy food [20], [21]. }\end{array}$ \\
\hline $\begin{array}{l}\text { Drakh } \\
\text { tik } \\
\text { Parasi } \\
\text { de }\end{array}$ & $\begin{array}{l}\text { Gegharkunik } \\
\text { region, } \\
\text { Drakhtik } \\
\text { village }\end{array}$ & $\begin{array}{l}\text { Beekeeping, mountai neering, beach, horse riding } \\
\text { [22], [23]. }\end{array}$ \\
\hline G omk & $\begin{array}{l}\text { Zaritap } \\
\text { community of } \\
\text { Vayots Dzor } \\
\text { region }\end{array}$ & $\begin{array}{l}\text { Horse riding, hiking, fishing, visiting historical } \\
\text { and cultural sites, participating in the preparation } \\
\text { of local dairy products, etc. [24]. }\end{array}$ \\
\hline $\begin{array}{l}\text { A pi- } \\
\text { cottages }\end{array}$ & $\begin{array}{l}\text { Alaverdi city of } \\
\text { Lori region }\end{array}$ & $\begin{array}{l}\text { Beekeeping study, the opportunity to enjoy the warm } \\
\text { air of the hive in specially made huts, teas made of } \\
\text { mountain herbs, horse riding and hiking [25]. }\end{array}$ \\
\hline $\begin{array}{l}\text { Darik } \\
\text { village }\end{array}$ & $\begin{array}{l}\text { Arpi community } \\
\text { of Shirak region }\end{array}$ & $\begin{array}{l}\text { Only one family is living in Darik with its cattle } \\
\text { farm: small cattle, gampres, Vietnamese pigs, } \\
\text { English and Austrian horses, local sheep, Armenian } \\
\text { gampr, Van cats, and roosters. The summer camp for } \\
\text { children in Darik all lows them to live an entire rural } \\
\text { life [26], [27]. }\end{array}$ \\
\hline $\begin{array}{l}\text { "Highlan } \\
\text { ds" Eco } \\
\text { Village } \\
\text { Resort }\end{array}$ & $\begin{array}{l}\text { Geghadir village } \\
\text { of Kotayk region }\end{array}$ & $\begin{array}{l}\text { Newly built houses made of Armenian tuff and } \\
\text { wood, gardens, vegetables, greens, herbs and } \\
\text { flowers, mountain farm Dogs, cats, donkeys, horses, } \\
\text { goats, chickens, ducks, geese, beehi ves, assorted } \\
\text { vodka, liqueur, and brandy are stored in the cellar. } \\
\text { Recommended lavash making master class, butter } \\
\text { making in an Armenian butter churn, honeycomb, } \\
\text { pai inting and carpet weaving lessons, video and } \\
\text { photo shooting in A menian national costume, }\end{array}$ \\
\hline
\end{tabular}




\begin{tabular}{|l|l|l|}
\hline & bicycle rental, horse riding, haying [28]. \\
\hline $\begin{array}{l}\text { "The end } \\
\text { of the } \\
\text { world" }\end{array}$ & $\begin{array}{l}\text { Norashen village } \\
\text { of Tavush region } \\
\text { who wish to get acquainted with the villagelife- } \\
\text { bake bread, milk a cow, offer to get acquainted with } \\
\text { thelife of a sailor, in case of sowing - participation } \\
\text { in the whole process of winemaking in wineries. } \\
\text { Adventurers are offered a visit to the cave, where } \\
\text { they light a bonfire, tastethymetea or coffee The } \\
\text { international model "Corn maze", during which } \\
\text { tourists visit the cornfields turned into labyrinths, is } \\
\text { also used here [29]. }\end{array}$ \\
\hline
\end{tabular}

\section{Representation of RA agro-tourism. The PR activity of the companies offering RA agro-tourism packages.}

The development of agro-tourism worldwide is a stimul us for the development of this type of tourism in A rmenia. It is facilitated by the United Nations Development Program (UNDP) project "Integrated Agricultural Tourism Development", which is funded by Russia [30].

The project helps villagers get funding and rebuild their homes, making it a destination for tour packages. "Armenian Association of Guest Houses development NGO" is following the renovation of the villagers' houses:

To reveal a more detailed representation of RA Agro-tourism and Public relations activities of companies offering RA agro-tourism packages, several qualitative interviews were conducted among the tourism companies employees operating in Armenia. Six employees from different organizations took part in the interview. Among those organizations were those that have started operating since 1994, and those that have started operating since 2018.

It turned out that travel companies include various elements of agro-tourism in their packages but do not offer packages whose main purpose is agro-tourism An employee of one of the travel companies says.

"As such, we do not have a special rural tourism department; we just visit villages as part of tours."

Familiarity with the offers of different travel companies indicates that agrotourism is offered to tourists, but it is only a small part of the overall package. All this can be an obstacle in the sense that foreign tourists do not perceive A menia as an agrotourism destination. Development is also hindered by the inaccessibility of the land borders of the Republic of Armenia; moreover, this circumstance is an obstacle for the development of all types of tourism, as the price of air tickets is high in the packages. It 
turns out that within the framework of Agro-tourism RA tourism companies offer services such as participation in the process of producing agricultural products, beekeeping, harvesting, vodka distillation, introduction to the winemaking process, various master classes, ovemight in traditional Armenian houses, cattle breeders, participation in various events, including festivals and courses/concerts involving national song or dance. Favourable climatic conditions in Armenia allow companies to operate from early spring to autumn.

"From the beginning of spring to the end of summer is the main season, because in those months rural tourismis more productive, it is the period of agricultural work, so tourists can be offered various master classes, harvesting, vodka distillation, acquaintance with the daily life of mountaineers, rural gastronomic tour".

As for the number of tour days, group tours are mostly one-day, and individual tours mainly depend on the tourist's personal preferences. Due to these circumstances, tour prices are changing.

According to the employees of the travel companies, mainly from Russia, France and Germany visit Armenia for agro-tourism. Moreover, the services are used by tourists of different age groups, both local and foreign. It is possible that these tourniquets are informed about the packages offered by the organization mainly from social networks and other tourists who use the service and have a positive opinion, and according to the opinion of the respondents, these are the most effective. In their view, the most effective platforms for advertising are the following: Facebook, Instagram, www.tripadvisor.com, ads placed on Google.

Both the analysis of the survey data and the study of advertisements frequency of various travel companies on the Internet show that advertisements are posted on social networks almost every day, even several times a day, and the videos show footage of tours al ready done as in Armenia. Ready-made videos about different places of interest. Some of these companies may also be registered on international platforms.

According to the employees of the travel companies, the packages offered in Armenia are competitive compared to the neighbouring countries, which is conditioned by the existence of historical sights, beautiful and rich nature.

On the other hand, the respondents consider the price of the packages as a disadvantage because they are more expensive than Georgia; besides, Armenia cannot offer desi rable packages for beach lovers.

Despite the mentioned shortcomings, Armenia continues to receive tourists from different countries. Based on the figures provided by the RA Border Electronic Management Information System (SECT), the Tourism Committee has published the number of visitors to Armenia in 2018-2019, which shows that in 2019 there was a $14.9 \%$ increase over the previous year, and according to official statistics - $14.7 \%$ growth. The five total visits in 2019 were made by the countries shown in the chart. 
Figure 1. The number of RA visitors in 2019 by countries [31].

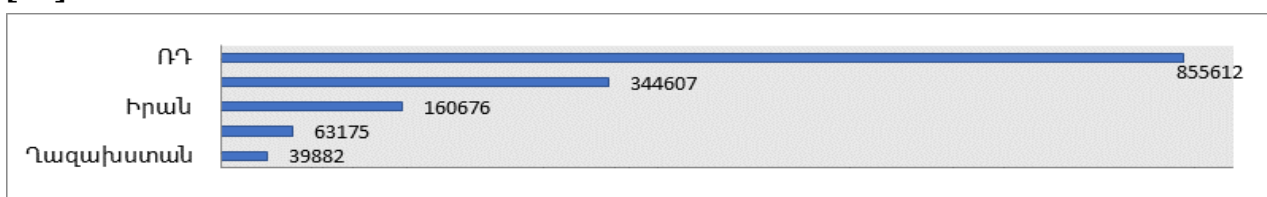

The data of the interviews were compared with the data of the documents analysis (the pages of the travel companies in different social networks, their publications were chosen as a document).

It should be noted that Armenia has all the conditions that can attract a tourist, but these services are not fully presented to Armenian-foreign tour operators, individual tourists. Now there are many institutions and villagers in Armenia who can welcome foreigners, introduce them to the Armenian culture and history, and offer them agro-tourism However, the growth of the number of users of their offers is hindered by the fact that there is no advertisement, package, information material on the Internet that will inform the tourist about the Armenian agro-tourism services.

Advertising is carried out for UN-funded gastro bakeries, which is done by the association. Materials are published about the opening of each gastro, which informs about the services provided by the location of the gastro. Armenian tour operators and various representatives of the tourism industry are invited to the opening ceremony of each new restaurant. This is the way of gastro advertisement.

Many guesthouses in different villages of Armenia are members of the Armenian Guest Development Association. Being a member of the association gives a brand to the guest house. These guest houses have a sign of association at their entrance. Being a member of the association means that the guest house provides highquality services. These guesthouses do not usually do personal advertising. Their advertisement is made by the association. Their advertisements provide a large influx of tourists to the guest houses, but they mostly use only overnight service. There are few tourists who use these services when they visit these guest houses and see that they provide agro-tourism

It can be said that Armenia is not properly represented as an agro-tourism destination.

\section{Conclusions and recommendations}

Tourism is one of the fastest-growing industries in the world economy. Along with the people's changing needs, various types of tourism are emerging, one of which is agro-tourism, which is associated with increasing levels of urbanization. It is also developing in Armenia, which is promoted by the beautiful nature and centuries-old 
culture. The construction of gastro bakeries opened as a result of the cooperation of the RA Tourism Committee cooperation and the UN greatly contributes to the revitalization of rural life Still, only gastro bakeries cannot be a stimulus for tourists, as advertising and cognitive tours are possible. Individual initiatives in different rural settlements, for example, Kalavan, Darik village, mean the development of agrotourism in Armenia. The "obstacle" here is the lack of advertising information on the Internet.

In conclusion, we can say that

1. agro-tourism has prospects for development in Armenia;

2. Agro-tourism can contribute to the development of different villages and communities in the Republic of Armenia;

3. Planning PR campaigns is a necessary precondition for development;

4. The lack of a common tourism platform in the Republic of Armenia hinders the development.

5. The development of packages offering rural tourism by Armenian tour operators will promote the development.

6. It is vital to create a network of guest houses, including only those guest houses engaged in agro-tourism

Thus, it is recommended.

1. Establish an organization attached to the Tourism Committee, which will raise the issues of agro-tourism in Armenia and look for new ways of development.

2. Regularly involve rural residents in rural tourism courses based on sufficient resources and Exchange experiences by getting acquainted with the agro-tourism potential of their village.

3. Create a unified website of agro-tourism in Armenia, where the potential of agrotourism in Armenia and the offered services will be presented, with the possibility of making online reservations.

4. Cooperate with foreign partners, organize information tours for them, exchange experience.

5. Invest in rural communities, which have all the resources to become an agrotourism destination. 


\section{REFERENCES}

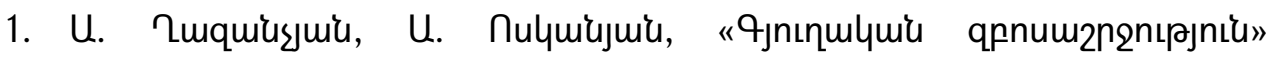

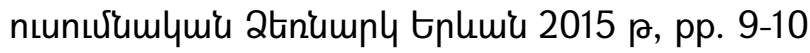

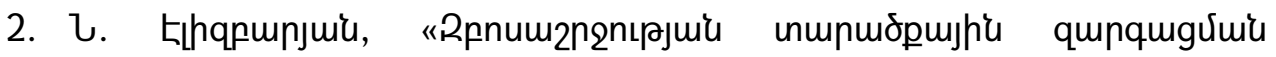

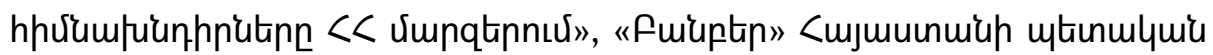

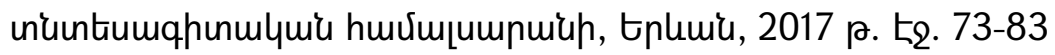

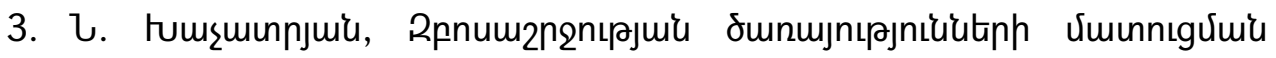

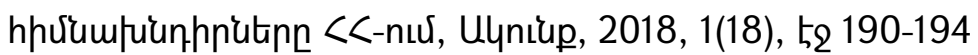

4. Socio-Cultural Impacts of International Tourism and the Impact on the Local Population - ArmSocClub (armsociology.com), 10.01.2020

5. Economic Impact Reports, ttps://www.wttc.org/economic-impact/, acc 10.01.2020

6. Customs and tourism and air transport, http://unwto.org/ru, acc 15.01.2020

7. Gegharkunik Agro, http://gegharkunik.agro.am/index.php/id=3418, acc.15.01.2020

8. Есодело, https://ecodelo.org/, acc. 23.01.2020

9. Rural Tourism, https://www.unwto.org/rural-tourism, acc. 30.06.2020

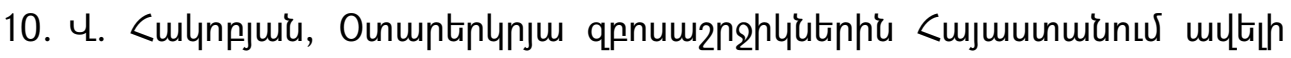
2min 5 uluti htinmpnpnts mqnnunnephquर्un, https://armenpress.am/arm/news/851577.html, acc. 15.03.2020

11. Snıphuinulquil umpatiplitip http://eunewsletter.am/hy/unnıphunulywiu 七U

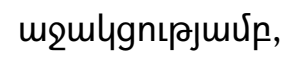

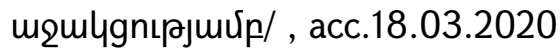

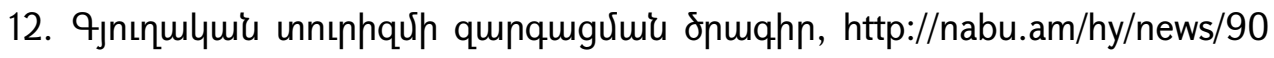
, acc. 19.03.2020

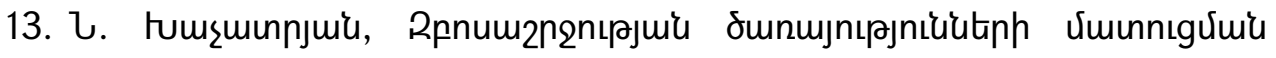
hhưumfuun_hnutinn 《<-nuर्u, http://www.ysu.am/files/7-1548055071-.pdf , acc. 19.03.2020

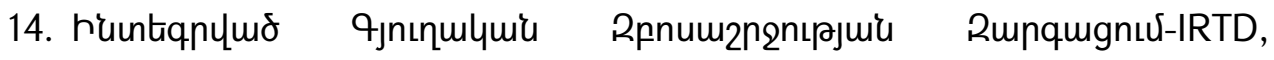
https://www.facebook.com/ruralArmenia/posts/1582400645240765, acc. 26.04.2020 
15. M. Mirzoyan, Turning Armenian Hospitality Into a Business Plan, https://regionalpost.org/en/articles/turning-armenian-hospitality-into-abusiness-plan.html, acc. 27.04.2020

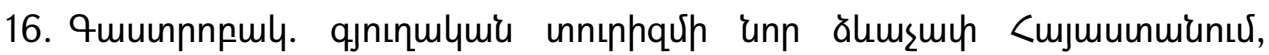
https://www.facebook.com/watch/?v=544546432764524, acc. 27.04.2020

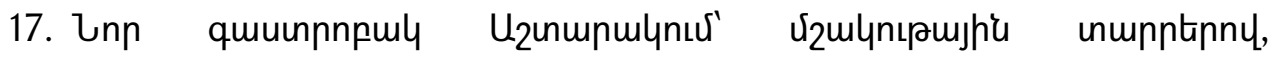
https://banks.am/am/news/newsfeed/18644, acc. 26.04.2020

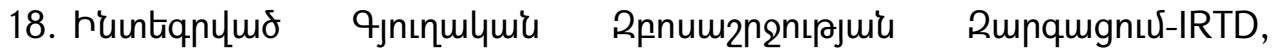
https://www.facebook.com/ruralArmenia/posts/1582400645240765?_tn_ $=K-R$, acc. 26.04.2020 24 .

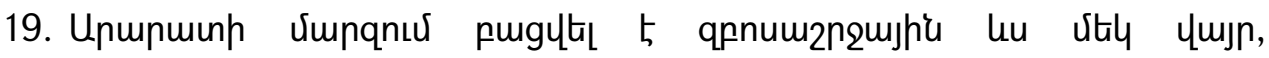
https://www.24news.am/news/81174, acc.26.04.2020

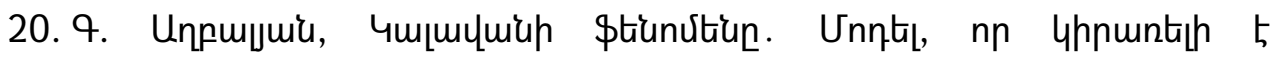
<mjuuunwuh qjnıntiph huviup, https://hetq.am/hy/article/78316, acc. 22.03.2020

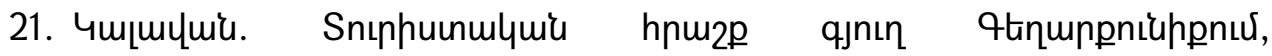
https://champord.am/kalavan-poqr-gyuxi-mec-hrashq/, acc. 22.03.2020

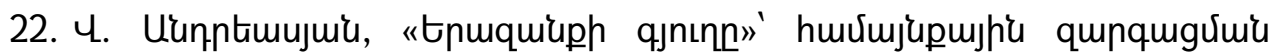
yunulyhs ophumul, https://banks.am/am/news/interviews/16218, acc. 23.03.2020

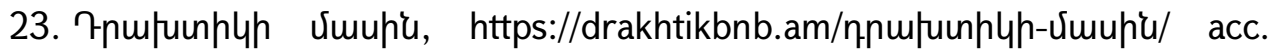
07.12 .2020

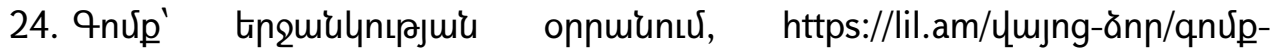

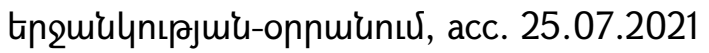

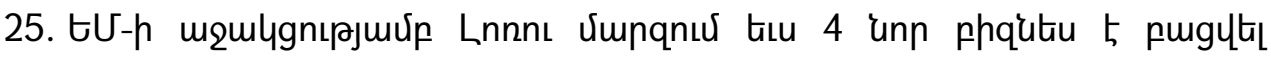
(\$nunn), https://news.am/arm/news/469469.html, acc. 07.112.2020

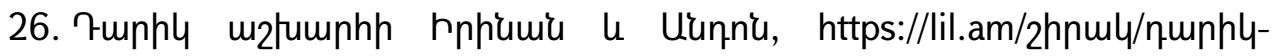
u2łumphh-hnhiumu-L-minnnu, acc. 26.03.2020

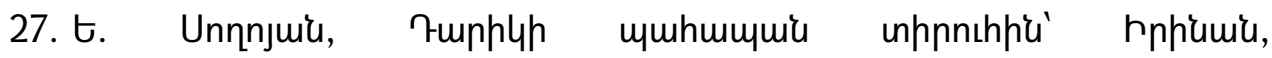
https://hetq.am/hy/article/91819, acc. 07.12.2020

28. HyeLandz, https://hy.hyelandz.com/about, acc. 07.12.2020

29. Corn Mazes America, https://www.cornmazesamerica.com/visitor_guide.ph p, acc. 02.04.2020 1:46 


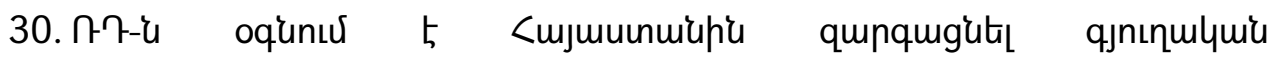
qpnumznenıرniun. Untiünnu pugytig quuinnnpuly https://armeniasputnik.am/tourism/20190417/18125174/rusastany-ognum-ehayastanin-zargacnel-gyuxakan-zbosashrjutyuny-arenium-bacvecgastrobak.html, acc. 02.04.2020

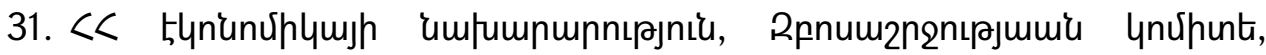
กınnunh 4h6umuqnnıpjnıu, https://www.mineconomy.am/page/89, acc. 12.04.2020

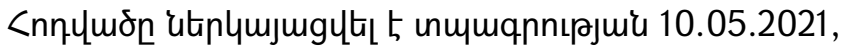

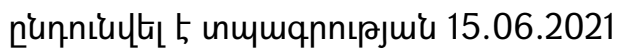

